\title{
Double blind placebo controlled trial of nebulised budesonide for croup
}

\author{
C W Godden, M J Campbell, M Hussey, J J Cogswell
}

\begin{abstract}
Aims-To determine whether nebulised budesonide improves the symptoms or shortens the duration of stay of children admitted to hospital with a clinical diagnosis of croup.

Methods-A prospective, randomised, double blind placebo controlled trial. Patients received either nebulised budesonide or placebo every 12 hours. The main outcome measures were duration of inpatient stay and croup scores at $\mathbf{3 0}$ minutes, one, two, four, 12, and 24 hours.

Results -87 patients ( 89 admissions) aged 7-116 months entered the trial. Nebulised budesonide was associated with a significant improvement in symptoms at 12 hours (95\% confidence interval (CI) 1 to 3$)$ and 24 hours (95\% CI 0 to 3). Patients with an initial croup score above 3 demonstrated a significant improvement in symptoms at two hours (95\% CI 1 to 3$)$. Nebulised budesonide was also associated with a $33 \%$ reduction in the length of stay $(95 \%$ CI $2 \%$ to $63 \%)$ when the confounding variables of age, initial croup score, and coryzal symptoms were taken into consideration.

Conclusions-Nebulised budesonide is an effective treatment for children admitted to hospital with a clinical diagnosis of croup.

(Arch Dis Child 1997;76:155-158)
\end{abstract}

Keywords: croup; budesonide.

Croup is an acute clinical syndrome characterised by inspiratory stridor, barking cough, and signs of respiratory distress due to laryngeal or tracheal obstruction. ${ }^{1-3}$ The treatment of croup remains controversial and mild cases probably require no treatment other than careful observation. Humidification has been used to treat croup since the 19th century but may not relieve symptoms whereas nebulised adrenaline has a beneficial effect but of limited duration. ${ }^{45}$ Oral steroids improve symptoms and reduce duration of intubation in children with croup. $^{6-8}$ Four previously published studies of nebulised steroids for the treatment of children with croup demonstrated clinical benefits after the administration of $2 \mathrm{mg}$ of nebulised budesonide in selected subgroups of patients. $^{8-11}$

In order to determine the efficacy of nebulised budesonide, in one hospital's total population of admissions with croup, we performed a prospective, randomised, double blind study.

\section{Methods}

Children with a clinical diagnosis of croup, admitted to the paediatric wards of Poole NHS Trust Hospital, between November 1993 and April 1995, were considered for the trial. Two months before the trial started a training package was introduced to familiarise qualified nurses with the croup score and the research protocol. The training included a video and practical experience of applying the croup score. These trained nurses performed the croup score throughout the trial. Before each child was enrolled in the study, the diagnosis was confirmed by the paediatric registrar and the parents were asked for informed consent. In order to maximise reproducibility the nurse performing the initial croup score would also, whenever possible, perform the later croup scores. Children were excluded if they were receiving bronchodilators or if they had received systemic steroids during the previous month. Children included in the trial received the standard care available. Westley's croup score $^{5}$ was modified (table 1). Oxygen saturation, temperature, heart rate, respiratory rate, presence of coryzal symptoms, and croup scores were recorded on admission. Randomised trial solution was supplied in an opaque Respule within a sealed silver foil packet (Astra Pharmaceuticals). The initial dose of nebulised budesonide was that used in previous studies. $^{8-11}$ The patient initially received $4 \mathrm{ml}$ of a solution containing either normal saline vehicle or $2 \mathrm{mg}(4 \mathrm{ml})$ of budesonide, via an opaque nebuliser chamber (system 22 Medic Aid), driven by wall oxygen at 8 litres a minute.

The optimum dose of budesonide and the ideal frequency of administration are unknown. However, as our study was continued throughout each child's stay on the ward, a regimen of repeating a dose of $1 \mathrm{mg}$ of budesonide or $2 \mathrm{ml}$ of normal saline vehicle every 12 hours was adopted.

The croup scores were performed on admission, at 30 minutes, one, two, four hours, and then every four hours until discharge. In order to obtain a better indication of the patient's clinical condition at 12 and 24 hours, the $12^{\star}$ hour croup score was defined as the mean of the eight, 12, and 16 hour croup scores and the $24^{\star \star}$ hour croup score as the mean of the 20 , 24 , and 28 hour croup scores. Total duration of hospital stay was recorded. Nebulised adrenaline $(0.5 \mathrm{ml} / \mathrm{kg}$ to a maximum of $5 \mathrm{ml}$ one in 
Table 1 Croup score (0-17)

\begin{tabular}{|c|c|c|c|c|c|}
\hline & $\begin{array}{l}\text { Oxygen saturation } \\
(\%)(0-4)\end{array}$ & Stridor (0-4) & Cough $(0-3)$ & $\begin{array}{l}\text { Recessions } \\
(0-3)\end{array}$ & $\begin{array}{l}\text { Respiratory } \\
\text { distress (0-3) }\end{array}$ \\
\hline 0 & $95-100$ & Nil & Nil & Nil & Nil \\
\hline 1 & $92-94$ & $\begin{array}{l}\text { Only when } \\
\text { agitated }\end{array}$ & Only when agitated & Mild & Mild \\
\hline 2 & $89-91$ & Mild at rest & Mild at rest & Moderate & Moderate \\
\hline 3 & $86-88$ & Moderate at rest & $\begin{array}{l}\text { Moderate-severe at } \\
\text { rest }\end{array}$ & Severe & Severe \\
\hline 4 & $<86$ & Severe at rest & - & - & - \\
\hline
\end{tabular}

1000) was used if clinically indicated and croup scores were not entered in the trial for the next two hours. ${ }^{5}$

After data analysis the patients' parents were informed of which trial solution their child had received. Duration of stay was approximately log normally distributed, so to compare the two groups a log transform was applied and linear regression performed to allow for confounding variables. The croup scores, at the previously specified times, were then compared by the Mann-Whitney U Test.

Because the shape of the response curve was uncertain a priori, it was decided to use the $12^{\star}$ and $24^{\star \star}$ hour croup scores as two of the main outcome variables and use a Bonferroni correction for two comparisons to assess significance. All $\mathrm{p}$ values were unadjusted.

Approval was obtained from the local ethics committee.

\section{Results}

During the study period 123 patients were admitted with a diagnosis of croup. The parents of 10 children with croup were not approached for consent due to manpower constraints.

Parental consent was obtained from 95 and refused by 18 of the remaining 113 patients. Observation sheets were reviewed before analysis by one of the authors (CWG) and six sets of data were excluded, five for the concomitant use of bronchodilators during the admission and one due to no data being available. The remaining 89 study admissions (87 children) included 59 boys and 28 girls with an age range of 7-116 months. During the study period two boys were admitted twice with croup. Seven of the 89 admissions failed to complete the study and data from these patients were included until withdrawal (table 2). The clinical characteristics on admission of the two groups were comparable (tables 3 and 4). During the trial, four patients in the control group received a total of 11 doses of adrenaline, and three patients in the study group received a total of four doses of adrenaline. Two patients, both in the control group, required intubation.

Duration of stay on the ward was skewed, ranging from six to 237 hours, with a study mean of 36 hours and a control mean of 55 hours.

Multiple regression identified age, initial croup score, and presence of coryzal symptoms as confounding variables. The admission croup score was strongly associated with length of stay $(\mathrm{p}<0.001)$ and there was an inverse relationship between length of stay and age $(\mathrm{p}=$ 0.017 ), with the youngest subjects staying on
Table 2 Withdrawals from study from 89 paediatric admissions with croup

\begin{tabular}{lll}
\hline Reason for withdrawal & Study group & Controls \\
\hline Nausea & 1 & 0 \\
Dislike of face mask & 1 & 0 \\
Dislike of saturation monitor & 1 & 0 \\
Endotracheal intubation & 0 & 2 \\
Parental request due to slow & 1 & 1 \\
$\quad$ progress & & \\
\hline
\end{tabular}

the ward longest. Children with coryzal symptoms tended to stay on the ward longer but this was not statistically significant $(\mathrm{p}=0.123)$. Treatment with budesonide was associated with a $33 \%$ reduction $(95 \%$ confidence interval $2 \%$ to $63 \%$ ) in length of stay when these three variables were included in the model $(\mathrm{p}=$ 0.038). The croup scores for the previously selected times are given in table 5 . A highly significant difference, in favour of the study group, is demonstrated at 12 and 24 hours.

\section{Discussion}

This randomised double blind placebo controlled trial has demonstrated a significant clinical benefit from the use of nebulised budesonide in children hospitalised with croup. The outcome measures used were duration of stay in hospital and croup scores at previously agreed times.

Previous studies using oral steroids for croup have demonstrated clinical improvements..$^{6-8}$ Nebulised steroids have the advantage of being deposited in the upper airway, have minimal systemic effects, and may have a more rapid onset of action than oral steroids. ${ }^{9}$ An Australian study of children hospitalised with croup demonstrated a similar significant improvement at one hour and a similar reduction in time spent in hospital with both oral dexamethasone and nebulised budesonide. ${ }^{8}$ A Canadian trial using nebulised budesonide for treating children with mild to moderate croup in an accident and emergency department demonstrated a clinical benefit at four hours, earlier discharge from outpatient follow up, and a reduced risk of admission to hospital. ${ }^{10} \mathrm{~A}$ Danish study described improved clinical scores in the treated group at two hours after nebulised budesonide. ${ }^{11}$ Combined treatment with nebulised budesonide and oral dexamethasone has also been demonstrated to lead to a faster improvement in symptoms than dexamethasone alone. ${ }^{9}$

Our study is the largest reported trial on the use of nebulised budesonide for croup and the only trial to include all patients irrespective of their initial croup score. It also differs from previous studies by the use of oxygen saturation as part of the clinical score and by providing clinical data over a longer duration of time. The effect of budesonide in croup at 30 minutes had not been investigated before but a previous study suggested an improvement at one hour. ${ }^{8}$ This supports results from animal studies that demonstrate an anti-inflammatory effect from topical but not systemic steroids evident from 40 minutes. ${ }^{12}$

No statistically significant improvement was evident at 30 minutes or one hour but this may be because of a lack of statistical power rather 
Table 3 Clinical characteristics on admission from 89 paediatric admissions with croup

\begin{tabular}{lll}
\hline & Study group $(n=47)$ & Controls $(n=42)$ \\
\hline $\begin{array}{l}\text { Mean age in months (range) } \\
\text { Male (\%) }\end{array}$ & $35.7(7-116)$ & $37.4(7-93)$ \\
Coryzal symptoms (\%) & $39(83)$ & $27(64)$ \\
Croup & & $29(69)$ \\
$\quad$ Mild (1-3) (\%) & $16 / 46^{\star}(35)$ & $15 / 41^{\star}(37)$ \\
Moderate (4-8) (\%) & $23 / 46^{\star}(50)$ & $20 / 41^{\star}(49)$ \\
Severe (9-17) (\%) & $7 / 46^{\star}(15)$ & $6 / 41^{\star}(15)$ \\
Respiratory rate/min (SD) & $33.9(8.9)$ & $33.8(8.5)$ \\
Heart rate/min (SD) & $131(21.3)$ & $129(18.5)$ \\
Temperature ( $\left.{ }^{\circ} \mathrm{C}\right)(\mathrm{SD})$ & $37.1(0.83)$ & $37.2(0.81)$ \\
\end{tabular}

${ }^{\star}$ The initial croup score from one patient from each group was not entered in the analysis due to prior treatment with nebulised adrenaline.

Table 4 Croup score parameters on admission from $87^{\star}$ paediatric admissions with croup; values are mean (SD)

\begin{tabular}{lll}
\hline & Study group $(n=46)$ & Controls $(n=41)$ \\
\hline Stridor (0-4) & $1.83(1.20)$ & $1.98(1.06)$ \\
Cough (0-3) & $1.37(1.00)$ & $1.15(0.88)$ \\
Recessions (0-3) & $0.80(0.89)$ & $0.78(0.93)$ \\
Respiratory distress (0-3) & $0.76(0.90)$ & $0.70(0.84)$ \\
Oxygen saturation score (0-4) & $0.58(0.87)$ & $0.49(0.95)$ \\
Croup score (0-17) & $5.30(3.44)$ & $5.15(3.70)$ \\
\hline
\end{tabular}

* The initial croup score from one patient from each group was not entered in the analysis due to prior treatment with nebulised adrenaline.

Table 5 Mean croup scores compared by the Mann-Whitney U test from 89 paediatric admissions with initial croup scores of 1-17

\begin{tabular}{lllll}
\hline Time (hours)t & Study group $\neq$ & Controls $\neq$ & Difference & p Value \\
\hline 0 & $5.30(\mathrm{n}=46)$ & $5.15(\mathrm{n}=41)$ & -0.15 & - \\
0.5 & $3.98(\mathrm{n}=45)$ & $4.41(\mathrm{n}=39)$ & 0.43 & 0.500 \\
1 & $3.11(\mathrm{n}=44)$ & $4.15(\mathrm{n}=40)$ & 1.04 & 0.120 \\
2 & $2.72(\mathrm{n}=46)$ & $3.98(\mathrm{n}=40)$ & 1.26 & 0.058 \\
4 & $2.34(\mathrm{n}=44)$ & $3.41(\mathrm{n}=39)$ & 1.07 & 0.100 \\
$12^{\star}$ & $1.89(\mathrm{n}=44)$ & $3.16(\mathrm{n}=41)$ & 1.27 & 0.001 \\
$24^{\star \star}$ & $1.16(\mathrm{n}=35)$ & $3.04(\mathrm{n}=32)$ & 1.88 & 0.005 \\
\hline
\end{tabular}

† Time in hours from initial nebulised trial solution.

$\ddagger \mathrm{n}=$ Number of patients with a croup score measured at that time.

$12^{\star}=$ Mean of the 8,12 , and 16 hour scores.

$24^{\star \star}=$ Mean of the 20,24 , and 28 hour scores.

The median croup scores (not shown above) demonstrated a similar trend.

Table 6 Mean croup scores compared by the Mann-Whitney $U$ test from 58 paediatric admissions with initial croup scores of 4-17

\begin{tabular}{lllll}
\hline Time (hours) $t$ & Study group $\neq$ & Controls $\neq$ & Difference & p Value \\
\hline 0 & $7.00(\mathrm{n}=31)$ & $6.96(\mathrm{n}=27)$ & -0.04 & - \\
0.5 & $5.17(\mathrm{n}=29)$ & $5.88(\mathrm{n}=25)$ & 0.71 & 0.440 \\
1 & $4.18(\mathrm{n}=28)$ & $5.42(\mathrm{n}=26)$ & 1.24 & 0.203 \\
2 & $3.43(\mathrm{n}=30)$ & $5.42(\mathrm{n}=26)$ & 1.99 & 0.013 \\
4 & $2.93(\mathrm{n}=28)$ & $4.63(\mathrm{n}=24)$ & 1.70 & 0.017 \\
$12^{\star}$ & $2.36(\mathrm{n}=25)$ & $3.64(\mathrm{n}=20)$ & 1.28 & 0.024 \\
$24^{\star \star}$ & $1.45(\mathrm{n}=20)$ & $3.23(\mathrm{n}=22)$ & 1.78 & 0.018 \\
\hline
\end{tabular}

† Time in hours from initial nebulised trial solution.

$\ddagger \mathrm{n}=$ Number of patients with a croup score measured at that time.

$12^{\star}=$ Mean of the 8,12 , and 16 hour scores.

$24^{\star \star}=$ Mean of the 20,24 , and 28 hour scores.

The median croup scores (not shown above) demonstrated a similar trend.

than the absence of a true treatment effect. When a subanalysis of the children in our study with moderate to severe disease was undertaken, a statistically significant benefit from treatment with nebulised budesonide was demonstrated from two hours (table 6). This early response to inhaled budesonide supports previous findings. ${ }^{8-11}$

Croup is a common condition but only about one child in 10 is admitted to hospital as most have only mild symptoms managed appropriately in their own homes. While all children require careful observation many mild cases may not need further treatment. The anti-inflammatory effects of oral steroids may take four hours to appear, but it has been sug- gested that topical steroids induce a more rapid change on mucosal surfaces by $\alpha$-adrenergic vasoconstriction. ${ }^{13}$ This early effect may be of clinical benefit but has also been observed using systemic steroids. ${ }^{8}$

No studies using nebulised budesonide in the community have been published in order to determine whether such treatment would improve symptoms, or reduce the hospital admission rate. For the more severe cases both oral steroids and nebulised budesonide have been used with benefit, but more controlled studies are required to determine which type of steroid treatment confers the greatest benefit. In this study we have shown that, in children hospitalised with croup, nebulised budesonide improves the croup score and reduces the time spent in hospital.

We thank Mrs Anne Homewood for her secretarial support.

1 Couriel JM. Management of croup. Arch Dis Child 1988;63:1305-8.

2 Skolnik NS. Treatment of croup. A critical review. Am $\mathcal{F}$ Dis Child 1989;143:1045-9.

3 Denny FW, Murphy TF, Clyde WA, et al. Croup: an 11 year study in a pediatric practice. Pediatrics 1983;71:871-6.

4 Bourchier D, Dawson KP, Fergusson DM. Humidification in viral croup: a controlled trial. Aust Paediatr f 1984;20: in viral $289-91$.

5 Westley CR, Cotton EK, Brooks JG. Nebulised racemic epinephrine by IPPB for the treatment of croup. Am $\mathcal{F}$ Dis Child 1978;132:484-7.

6 Tibballs J, Shann FA, Landau LI. Placebo-controlled trial of prednisolone in children intubated for croup. Lancet 1992; 340:745-8.

7 Kairys SW, Olmstead EM, O'Connor GT. Steroid treatment of laryngotracheitis: a meta-analysis of the evidence from randomized trials. Pediatrics 1989;83:683-93.

8 Geelhoed GC, Macdonald WBG. Oral and inhaled steroids in croup: a randomised placebo-controlled trial. Pediatr Pulmonol 1995;20:355-61.

9 Klassen TP, Watters LK, Feldman ME, et al. The efficacy of nebulised budesonide in dexamethasone-treated outpatients with croup. Pediatrics 1996;97:463-6.

10 Klassen TP, Feldman ME, Watters LK, et al. Nebulised budesonide for children with mild-moderate croup. N Engl fMed 1994;331:285-9.

11 Husby S, Agertoft L, Mortenson S, et al. Treatment of croup with nebulised steroid (budesonide): a double blind, with nebulised steroid (budesonide): a double blind
placebo controlled study. Arch Dis Child 1993;68:352-5.

placebo controlled study. Arch Dis Child 1993;68:352-5.
12 Miller-Larsson A, Brattsand R. Topical anti-inflammatory Miller-Larsson A, Brattsand R. Topical anti-inflammatory
activity of the glucocorticoid budesonide on airway mucosa. Evidence for a 'hit and run' type of activity. Agents Actions 1990;29:127-9.

13 Brown PH, Teelucksingh S, Matusiewicz SP, et al. Cutaneous vasoconstrictor response to glucocorticoids in asthma. Lancet 1991;337:576-8.

\section{Commentary}

There has been a clear evidence-based change of policy in the management of croup over the past six or seven years. In 1989 a meta-analysis of nine well conducted studies of the use of corticosteroids in croup produced clear evidence of benefit. ${ }^{1}$ Since then the debate has changed from whether to prescribe corticosteroids, to which corticosteroid, and when.

The paper by Godden et al is the fifth published indicating benefit for the use of nebulised budesonide..$^{2-5}$ All papers have shown improvements in different arbitrary designed 'croup scores' and this one and two others show children are discharged from hospital significantly earlier. ${ }^{24}$

Other studies have looked at the value of oral dexamethasone. Geelhoed and Macdonald in their three pronged trial compared oral dexamethasone $0.6 \mathrm{mg} / \mathrm{kg}$ with nebulised budesonide and placebo in hospitalised patients. ${ }^{4}$ When duration of admission and reduction in croup 
scores were compared both drugs were better than placebo. There was no statistical difference between budesonide and dexamethasone but the trends both for onset of action and duration of admission were in favour of the oral drug. The second Geelhoed and Macdonald study compared oral dexamethasone at doses of $0.6,0.3$, and $0.15 \mathrm{mg} / \mathrm{kg}$ in two sequential double blind randomised trials and found that $0.15 \mathrm{mg} / \mathrm{kg}$ was as effective as the other doses in relieving symptoms and in duration of hospitalisation. ${ }^{6}$ This group has recently demonstrated that $0.15 \mathrm{mg} / \mathrm{kg}$ of oral dexamethasone given for mild croup in patients treated as outpatients reduces the need for reattendance at hospital.

One study of nebulised budesonide versus placebo given in addition to oral doses of dexamethasone $0.6 \mathrm{mg} / \mathrm{kg}$ in children with mild to moderate croup 5 showed advantage in croup score at four hours for dual treatment but no difference in the numbers admitted to hospital.

Where does all this evidence leave us when deciding the best treatment for the child in casualty? Clearly both drugs are effective and safe. However, most croup is benign and self limiting and probably well under $10 \%$ of cases ever attend hospital. Treatment should be reserved for those who need it, should be of optimal clinical effectiveness, and should be cost effective.

Crying and agitation exacerbates stridor. There needs to be considerable advantage before a small, anxious, and bewildered child is held still for 10 minutes while a mask is placed over the face to deliver a nebulised drug. Everard et al have demonstrated that close application of mask to face is needed to ensure good drug delivery from a nebuliser. ${ }^{8}$ For the majority of young children this treatment will, at least in the short term, increase distress.

Nebulised budesonide is a costly drug; $2 \mathrm{mg}$ of budesonide costs $£ 4.46$ (\$6.90) at British National Formulary prices and added to that are the costs of disposable equipment and the nursing costs of administration. A $2 \mathrm{mg}$ dexamethasone tablet is soluble in water and costs $£ 0.04$ (\$0.06). The appropriate dose $(0.15 \mathrm{mg} / \mathrm{kg}$ rounded up to the nearest $0.5 \mathrm{mg})$ can be given by mouth without distress in very little time. Over 100 children could be treated with oral dexamethasone for the cost of one treated with nebulised budesonide.

In conclusion:

(1) If croup is mild (a barking cough and hoarseness with no stridor or recession at rest) no treatment is needed.

(2) Treatment of significant croup with corticosteroids is good practice and cost effective. Oral dexamethasone is as effective, easier to administer, and cheaper than nebulised budesonide and is the drug of choice.

Widespread adoption of this policy could result in significant savings to the NHS. It is difficult to estimate the number of children who might avoid hospital admission but extrapolating from Geelhoed's outpatient data one admission and eight reattendances might be prevented for every 50 patients treated $(50 \times$ $\left.£ 0.04(0.06 \mathrm{c})=£^{2}(\$ 3.10)\right)$. Substantial savings could also come from reducing duration of admission. Geelhoed and Macdonald's inpatient study ${ }^{4}$ shows reduction in hospital stay of approximately eight hours. For every 100 patients treated 800 hospital hours could be saved and all for less than a fiver-Wow!

ANNE H THOMSON Oxford Radcliffe Hospital NHS Trust, Headington, Oxford OX3 9DU

1 Kairys SW, Olmstead EM, O'Connor GT. Steroid treatment of laryngotracheitis: a meta-analysis of the evidence from randomised trials. Pediatrics 1989;83:683-93.

2 Klassen TP, Feldman ME, Watters LK, et al. Nebulised Klassen TP, Feldman ME, Watters LK, et al. Nebulised
budesonide for children with mild-moderate croup. $N$ Engl

3 Husby S, Agertoft L, Mortenson S, et al. Treatment of croup with nebulised steroid (budesonide): a double blind, with nebulised steroid (budesonide): a double blind,
placebo controlled study. Arch Dis Child 1993;63:352-5.

4 Geelhoed GC, Macdonald WBG. Oral and inhaled steroids in croup. A randomised placebo-controlled trial. Pediatr Pulmonol 1995;20:355-61.

5 Klassen TP, Watters LK, Feldman ME, et al. The efficacy of nebulised budesonide in dexamethasone treated outpatients with croup. Pediatrics 1996;97:463-6.

6 Geelhoed GC, Macdonald WBG. Oral dexamethasone in the treatment of croup: $0.15 \mathrm{mg} / \mathrm{kg}$ versus $0.3 \mathrm{mg} / \mathrm{kg}$ versus $0.6 \mathrm{mg} / \mathrm{kg}$. Pediatr Pulmonol 1995;20:362-8.

7 Geelhoed GC, Turner J, Macdonald WBG. Efficacy of a small single dose of oral dexamethasone for out-patient croup: a double-blind placebo controlled trial. BMF 1996; 313:140-2.

8 Everard ML, Clark AR, Milner AD. Drug delivery from jet nebulisers. Arch Dis Child 1992;67:586-91. 